\title{
Europe as a Regional Actor: Waning Influence in an Unstable and Authoritarian Neighbourhood
}

Citation for published version (APA):

Pomorska, K., \& Noutcheva, G. (2017). Europe as a Regional Actor: Waning Influence in an Unstable and Authoritarian Neighbourhood. Journal of Common Market Studies, 55(S1), 165-176.

https://doi.org/10.1111/jcms.12612

Document status and date:

Published: 01/09/2017

DOI:

10.1111/jcms.12612

Document Version:

Publisher's PDF, also known as Version of record

Document license:

Taverne

Please check the document version of this publication:

- A submitted manuscript is the version of the article upon submission and before peer-review. There can be important differences between the submitted version and the official published version of record.

People interested in the research are advised to contact the author for the final version of the publication, or visit the DOI to the publisher's website.

- The final author version and the galley proof are versions of the publication after peer review.

- The final published version features the final layout of the paper including the volume, issue and page numbers.

Link to publication

\footnotetext{
General rights rights.

- You may freely distribute the URL identifying the publication in the public portal. please follow below link for the End User Agreement:

www.umlib.nl/taverne-license

Take down policy

If you believe that this document breaches copyright please contact us at:

repository@maastrichtuniversity.nl

providing details and we will investigate your claim.
}

Copyright and moral rights for the publications made accessible in the public portal are retained by the authors and/or other copyright owners and it is a condition of accessing publications that users recognise and abide by the legal requirements associated with these

- Users may download and print one copy of any publication from the public portal for the purpose of private study or research.

- You may not further distribute the material or use it for any profit-making activity or commercial gain

If the publication is distributed under the terms of Article $25 \mathrm{fa}$ of the Dutch Copyright Act, indicated by the "Taverne" license above, 


\title{
Europe as a Regional Actor: Waning Influence in an Unstable and Authoritarian Neighbourhood
}

\author{
KAROLINA POMORSKA and GERGANA NOUTCHEVA
}

Maastricht University

\section{Introduction}

Two years ago, Ana Juncos and Richard Whitman asked whether the EU neighburhood was 'lost' and argued that Europe's political and economic influence in its neighbourhood was marginal (Juncos and Whitman, 2015, p. 212). A couple of years later we confirm the trend of waning EU influence and maintain that the EU has been reactive in its approach to the unfolding crises in the neighbourhood but unable to advance its strategic priorities through a more pro-active foreign policy. 2016 turned out to be yet another eventful year where we observed little positive progress in terms of moving towards democracy and stability.

While it is not unusual that a large part of the foreign policy agenda is set by current events and crises, the need for a strategic approach had been recognized by policy-makers in Brussels. On the basis of a mandate from the member states, the High Representative for Common Foreign and Security Policy (CFSP), Federica Mogherini, was tasked to introduce a more forward-looking method of foreign policy-making in the process of rethinking the European Global Strategy. Almost at the same time, the European Commission engaged in a major exercise of reviewing the European Neighbourhood Policy (European Commission, 2015a). As a result, on both occasions, the European institutions marked a departure from the 'period of optimism for the EU' (Hahn, 2016, p. 1) when the EU policy was loaded with normative goals and proclaimed a turn towards 'pragmatic idealism' (European Union, 2016) entailing a more interest-driven agenda with an explicit focus on security.

We posed the question of 'values versus security' in a volume we edited back in 2013 (Noutcheva et al., 2013). Needless to say, these two foreign policy objectives are driven by different logics that may contradict each other but the relationship between them is rather complex and should be approached without pre-conceived expectations of an inevitable clash. What we observe in the neighbourhood in 2016 is a Union responsive to manifold crises that have activated the security concerns of the member states in the short run and crowded out the space for pro-active policies advancing the EU's long-term normative goals in the neighbouring countries. We also witness manifestations of the long-standing divergence on normative and security questions among the member states that have at times pushed a policy line at the EU level that is suboptimal from both a normative and a security perspective. We also discern the foreign policy consequences of a normatively weakened EU from within, with internal challenges to its democratic integrity undermining its external democracy support agenda.

In this contribution we examine the responses of the EU to the authoritarian turn in the European neighbourhood on the one hand and the handling of the multiple security crises 
on the other hand. We first present the authoritarian turn in the EU's wider neighbourhood and analyze the ways in which the Union has responded to it. We then turn to security challenges and review the EU's efforts to address them.

\section{The Authoritarian Turn in the EU's Wider Neighbourhood}

In 2016, authoritarian rule continued its march across the wider European neighbourhood. The authoritarian temptation has been strong in both the enlargement countries from the Western Balkans and Turkey and the neighbourhood countries from Eastern Europe and the Middle East and North Africa (MENA). Turkey experienced a violent military coup attempt that ultimately played into the hands of the Turkish President Recep Erdoğan by giving him a blank cheque to consolidate his authoritarian rule. While the reaction of Turkish society to the attempted military coup in July 2016 was widespread condemnation, affirming a strong societal norm against military intervention in political life (Ülgen, 2016), the aftermath unleashed the worst downgrade of Turkish democracy in the last decade. Turkey's President blamed the attempted coup on the US-based cleric Fethullah Gülen, the leader of a popular religious movement in the country alleged to pose a threat to Erdoğan's rule. Claiming to prosecute Gülenist sympathizers for their alleged support for the July failed coup, the Turkish President and the ruling Justice and Development Party (AKP) launched a massive purge of the military, judiciary, public administration, academia, media and other suspected pockets of political opposition. More than 70,000 people are said to have been taken into custody in the weeks following the failed coup, which included an estimated 7,000 members of the Turkish army, over 2,000 Turkish judges, more than 7,000 police officers, and many more civil servants, journalists, university professors, lawyers, politicians. ${ }^{1}$ The repression against Gülen followers coincided with a tightening grip on power of the AKP government which managed to establish a firm control over the state machinery and media in the country, crushing any hope of a democratic revival (Bechev, 2016a).

In the Western Balkans, the erosion of the democratic advances of the early 2000s has been ongoing for about a decade and all major democracy indices show that the region is now at the same level of democratic achievement that it was in the mid2000s (Freedom House, 2017; see also Figure 1). The scale of democratic backsliding may even be greater than suggested considering the informal power structures, patronage and nepotism characterizing the Balkan polities (BiEPAG, 2017). Macedonia took most of the headlines in 2016 owing to the political crises triggered by the wiretapping affair of 2015 and incriminating the senior political echelons of the ruling centre-right party. The scale of political wrongdoing in the country created shock waves as it involved allegations of massive surveillance of journalists, political opponents, police officers, judges, vote-buying and voter intimidation, political interference in judicial cases and even the cover-up of a murder. ${ }^{2}$ The situation was further aggravated by a presidential pardon of all politicians implicated in the scandal. Macedonia is not the only country affected by the observed backlash against democratic freedoms which has engulfed most of the countries from the region. Only Kosovo and

\footnotetext{
${ }^{1}$ Independent, 8 October 2016.

${ }^{2}$ RFERL, 15 April 2016.
} 
Figure 1: The authoritarian turn in the wider European neighbourhood. [Colour figure can be viewed at wileyonlinelibrary.com]

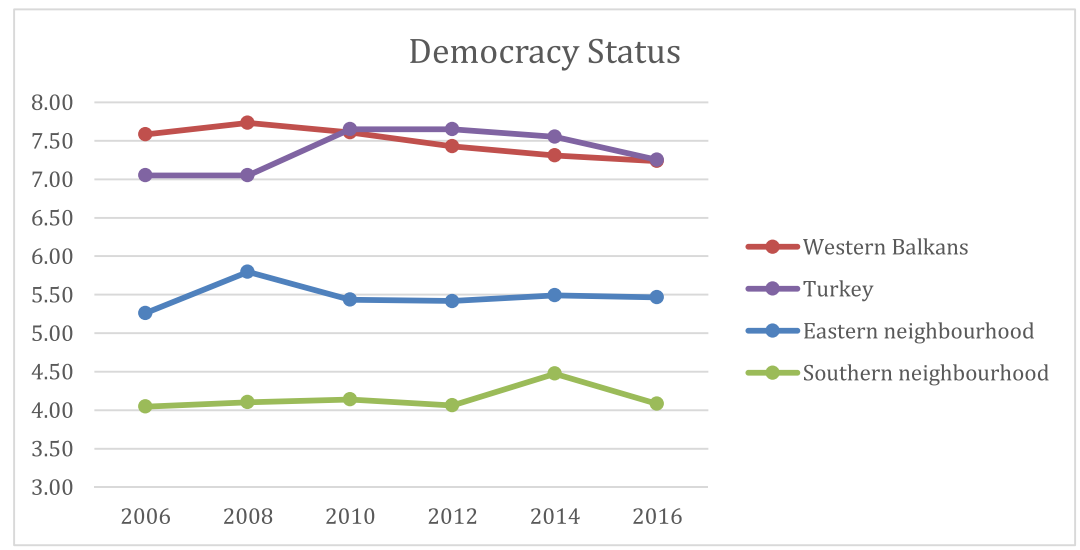

Source: Bertelsmann Stiftung Transformation Index, Democracy Status.

Note: Rating on a scale of one (the lowest value) to 10 (the highest value). Israel and Palestine not included in the average score for the Southern neighbourhood. Kosovo is included with a separate rating in the average score for the Western Balkans as of 2010 onwards.

Montenegro made marginal gains in democratic governance in 2016, with Kosovo moving up to the Freedom House category of 'hybrid regime' for the first time (Freedom House, 2017).

Stagnation or regression on political freedoms and rule of law characterized developments in the southern neighbourhood as well in 2016, with only a few exceptions to the dominant trend of deepening authoritarianism. The MENA region saw new depths of authoritarian misrule in 2016 with Syria, Libya and Yemen plagued by devastating wars bringing additional degradation of human freedom (Freedom House, 2017). The regime in Egypt continued to rule unabated, successfully crushing all opposition voices and limiting further the room for civil society activism. Only Tunisia persisted in safeguarding its democratic gains even against the backdrop of economic hardship and defying the regional trend.

The eastern neighbourhood, generally considered more plural and prone to political change, did not produce much positive news in 2016. Georgia and Moldova, both previously viewed as 'success stories' (Boonstra, 2011), showed no signs of building upon earlier democratic advances, with Moldova continuing to drift after the banking scandal of 2014. The two strongest authoritarian regimes in the region - Azerbaijan and Belarus - remained in the same category although Belarus witnessed some modest changes towards a political thaw in 2016. President Alexander Lukashenko released the last of the political prisoners, while later elections were thought to be the most open in the recent history of the country with two independent candidates gaining seats in the parliament. Still, Belarus activists remained critical, emphasizing that opposition candidates were 'appointed to appease the west' and nothing much had changed. ${ }^{3}$ Only

3 The Guardian, 12 September 2016. 
Ukraine registered marginal improvements of its democracy score in 2016 although doubts about its future democratic trajectory persist (Freedom House, 2017).

\section{Responding to Authoritarianism in the European Neighbourhood}

The tone for the EU's response to the multiple challenges in the European neighbourhood was set in the European Neighbourhood Policy review published in November 2015 (ENP Review, 2015). In this document, the EU defined stabilization of the neighbourhood as its overarching goal, retreating from its previously lofty democracy rhetoric. The democracy and good governance agenda has been toned down at the expense of a heightened interest in developing security co-operation and partnerships with all neighbours. This notable change in the ENP narrative was a precursor of the pragmatic turn in EU foreign policy confirmed with the release of the Global Security Strategy in 2016 (European Union, 2016). In theory, the enlargement countries continue to be subject to EU's democracy conditionality but in practice, the EU's paramount interest in stability has trumped the EU's actual support for democracy even in the accession context (BiEPAG, 2017). The EU's explicit stance on prioritizing stability over democracy thus rhetorically acknowledged a long-time foreign policy practice.

This officially announced choice coincided with a period of waning normative appeal of the EU owing to deteriorating democracy standards in some of its own member states. In 2016, the EU's democratic reputation continued to be severely tarnished by democratic backsliding in Hungary and Poland and the perceived inability of the EU to decisively intervene and reverse the negative trend in its own house. Throughout 2016, Poland has been receiving very heavy criticism from the Council of Europe's Venice Commission and the European Commission for failing to publish the judgments of the Constitutional Tribunal and for undermining the status and operations of this core state institution (European Commission, 2016b). However, this naming and shaming has not had much effect to date. While the Commission continued sending recommendations to the Polish government, it fell short of activating Article 7 TEU, which states that the violation of the EU's basic values may be punished with sanctions. Hungary's backsliding on democratic governance predates that of Poland when the European Commission's 'Rule of Law Framework', currently applied to Poland, did not exist. Nevertheless, the reforms undertaken by Prime Minister Viktor Orbán remain a serious matter of concern for his European partners, yet no serious sanctioning has taken place so far. ${ }^{4}$

This muted response has projected an image of weakness with regard to both the EU's capacity to inspire by being an example and its capacity to act convincingly in support of democracy when faced with serious breaches of democratic principles. As a result, the EU's democratic legitimacy abroad has suffered and nowhere is this felt more strongly than in the Western Balkans where the prospect of future EU membership has not proved a strong anchor for genuine democratic reforms so far. The ruling political elites in the region are not interested in losing power for the sake of long-term benefits that a future EU membership might eventually bring. And the Balkan societies are disappointed with a weak EU that fails to discipline their ruling elites through exposing and sanctioning

\footnotetext{
${ }^{4}$ See Dinan's contribution to this volume.
} 
illiberal practices. A 2016 public opinion survey across the countries from the region shows that only in Albania and Kosovo does an overwhelming majority (over 80 per cent) view EU membership as a positive thing (Balkan Barometer, 2016). Public perceptions of the EU are particularly worrying in Serbia and in Bosnia and Herzegovina where the EU is seen positively by only a minority ( 21 per cent and 33 per cent, respectively) (Balkan Barometer, 2016).

The EU's overall reaction to the worsening political governance standards in the wider neighbourhood in 2016 can thus be viewed as a re-run of the dilemma of acting strategically and securing its own interests versus playing it normatively and standing up for its values. The response from the EU to the Turkish military coup is one such example. Having made a deal with Turkey on migration in March, on the basis of which Turkey had been receiving money in exchange for keeping the refugees on its territory (preventing irregular migration) and aware of the important role and ambitions of Turkey in the Middle East, the EU member states were reluctant to use any stronger diplomatic instruments, even after they agreed that standards of democracy were falling fast. Turkey, for its part, then used the deal to press for a visa-waiver policy on the part of the EU. Similar deals to that with Turkey had been made with other countries, such as Mali, Nigeria, Senegal, Ethiopia and Niger.

What followed in the aftermath of the coup was a rapid worsening of the EU-Turkey relationship. In November, the European Commission (2016a) issued a 102-page report about the situation in Turkey, including criticism of President Recep Erdoğan's reaction to the coup. It called for a greater respect for human rights and expressed a 'grave concern' over the arrest of the Kurdish opposition. It also pinpointed a 'serious backsliding' in freedom of speech. Next to the Commission's reaction, the High Representative for Common Foreign and Security Policy Federica Mogherini released a declaration on behalf of the EU (Council of the EU, 2016a), also expressing 'grave concern' and advocating returning to 'a credible political process' as essential for democracy and stability in the region. This was met with an objection from Ankara, with the foreign minister condemning the report as being 'very far' from objective and for not being 'constructive and offering a way forward' 5 The relationship further deteriorated at the end of the year when Austria threatened to block the Turkish accession talks and, subsequently, Turkish officials engaged in aggressive discourse against Austria, with Turkish Foreign Minister Mevlut Cavusoglu claiming that Turkey would 'take action against Austria at all levels and on all issues' ${ }^{6}$ and comparing the rhetoric of the Austrian foreign minister to that of a 'racist party'. Austria's bid to freeze Turkey's accession talks was not accepted by the other member states, which emphasized their commitment to the deal on migration.

Migration concerns also acted against a strong EU role in support for democracy in the Western Balkans. The co-operation of the Western Balkan countries in closing down the so-called Balkan migrant route proved more valuable to some EU member states than democracy in the region and ultimately prevented the EU from openly criticizing and taking action against the democratic breaches in the region. The Western Balkans came to the forefront of the international migration crisis in 2015 when the flow of people

\footnotetext{
${ }^{5}$ Politico, 9 November 2016.
}

${ }^{6}$ Politico, 16 December 2016. 
seeking refuge in the EU from war and political prosecution in Syria, Iraq and Afghanistan reached record numbers. In particular, Serbia and Macedonia stood on the migrants' route to Hungary and western Europe and saw their territories flooded by transiting foreigners demanding help. While the EU struggled to come up with a unified approach, Hungary and Austria defied Germany's 'open door' policy and pushed the closing down of the Balkan route by unilaterally shutting their frontiers to asylum seekers stranded in Greece and wishing to reach Germany (Bechev, 2016b). The EU officially declared the Western Balkans migrant route closed in March 2016 as a result of which the illegal border crossings on the route dropped to 122,779 in 2016 from the record 764,038 in $2015 .^{7}$

Balkan strongmen thus became indispensable partners in managing the EU's refugee crisis while deteriorating local media freedom and judicial independence and worrying signals of state capture met no serious opposition either internally or externally. Balkan governments happily accepted the role of gatekeepers of Europe as it gave them leverage over Brussels and spared them criticism on domestic issues (Bechev, 2016b). In Macedonia, the EU's mediation team of Commissioner Johannes Hahn and Members of the European Parliament Richard Howitt, Eduard Kukan and Ivo Vajgl continued to put pressure on the main political parties to come to an agreement on holding early parliamentary elections and implementing the EU-brokered Pržino agreement of 2015. This did not prevent Austria's Foreign Minister Sebastian Kurz appearing at a rally of the ruling VMRO-DPMNE party in November 2016 offering his support for a political actor that has presided over Macedonia's slide into authoritarianism in the last decade. ${ }^{8}$ Similarly, the EU continued to hail Belgrade and Pristina for the advances in the EUfacilitated High Level Dialogue for normalization of relations between them (EEAS, 2016). At the same time, critics have been ever more vocal on Serbia's turn toward more authoritarian domestic practices with the EU remaining silent on the matter (BiEPAG, 2017).

In the eastern neighbourhood, the geopolitical competition with Russia over the foreign policy orientation of the countries from the shared neighbourhood has entailed faster delivery of rewards to the pro-EU partners without much consideration of the local democracy standards. In July 2016, the Association Agreements with Moldova and Georgia took effect. Georgia and Ukraine made a decisive step towards visa-free travel in the Schengen area in 2016, with both the EU member states and the European Parliament giving their green light to visa-free regimes with the two countries. And while the underlying logic has been providing support for the struggling pro-democracy forces in these countries, the outcome has been rewarding democratic underperformance and indirectly encouraging complacency.

As regards the eastern partners that have opted out of political association with the EU, there have been attempts to engage them while keeping apart geopolitical and normative differences. The EU thus negotiated in the course of 2016 a new, legally binding and overarching agreement with Armenia meant to replace the Partnership and Cooperation Agreement (PCA) currently in force and laying the ground for political, economic and sectoral co-operation with the country. A similar comprehensive pact is expected to be

\footnotetext{
${ }^{7}$ http://frontex.europa.eu/trends-and-routes/western-balkan-route/

${ }^{8}$ BalkanInsight, 28 November 2017.
} 
negotiated with Azerbaijan as well. This policy is in line with the new ENP approach of partnership with all, without pre-conditions and imposition of a normative agenda.

As regards Belarus, relations have always been difficult, with the European Union making several U-turns in its approach to the country, searching for any viable way to influence the regime in Minsk. While Belarus, experiencing the economic downturn since 2014, may soon witness 'a clampdown in Minsk or an incursion from Moscow' (Wilson, 2017), the EU still does not seem well-prepared to respond to any of these options. Following the 2014 Russian annexation of Crimea, President Alexander Lukashenko played a balancing game between the West and Russia, taking on a role of negotiator of the ceasefire, remaining vague on the legality of the Russian intervention and opposing the increased Russian military presence in his country. This went hand-in-hand with yet another cautious warming-up of the relations between the European Union and Belarus. In February 2016, the Foreign Affairs Council adopted conclusions on Belarus, which lifted the sanctions on 170 individuals but kept the weapons embargo and sanctions over the disappearance of individuals. The Council remained 'open to the further development of EU-Belarus relations, and to taking further steps to enhance political relations and sectoral cooperation in the appropriate context' (Foreign Affairs Council, 2016a). In 2016, the EU doubled the bilateral assistance package to Belarus from $€ 14.5$ million in 2015 to $€ 29$ million. While most of the funds were aimed at strengthening the private sector, $€ 2$ million was earmarked for support to the European Humanities University in Vilnius. Founded in Minsk in the early 1990s, the university was forced to move out of Belarus in 2004 and has continued its existence in Lithuania ever since.

In the southern neighbourhood, the EU's leverage is much weaker in a geopolitical setting characterized by multiple actors vying for influence and a societal context distinguished by weaker identification with Europe. The hopes ushered by the Arab Spring in 2011 have long given place to more sober assessments of the prospects for democracy in the region. The deepening authoritarian trend in the MENA has not changed the EU's policy of always putting stability first (Dandashly, 2015). In 2016 the emphasis has once again been on managing the instability generated by the conflicts in Syria, Libya and Iraq and the ensuing consequences for the security of the EU, most notably with respect to the refugee flows towards Europe from the region and the rise of the Islamic State (ISIS). While EU member states argued bitterly over how to provide safety to the Syrian refugees, European institutions were actively seeking ways to pool resources and offer additional financial support to Jordan, the country most heavily hit by the Syrian refugee crisis. Jordan alone is said to host over 1.2 million refugees on its territory. The EU has hailed Jordan's contribution to managing the refugee crisis and has allocated $€ 1.25$ million since 2011 in financial assistance to the country, with the bulk of the money earmarked for refugees. ${ }^{9}$ In addition, with the multiplication of ISIS-backed terrorist attacks in the EU member states, public pressure has also intensified on the national governments to show resolve in tackling the terrorist threat believed to emanate from the region. Counting on the co-operation of the authoritarian regimes in the southern neighbourhood has thus been of paramount importance for the security interests of the EU.

${ }^{9}$ https://eeas.europa.eu/sites/eeas/files/9_jordan_3pg.pdf. 
Tunisia has been the outlier in this context making steady progress on democracy notwithstanding the difficult regional environment and unfavourable domestic conditions. The EU continued to support this positive development throughout 2016, adopting a Joint Communication 'Strengthening EU support for Tunisia' (European Commission, 2016c) in September and making available to the country all instruments it has at its disposal in the context of the ENP, such as negotiations on a future Deep and Comprehensive Free Trade Agreement, negotiations on a visa facilitation agreement and a readmission agreement, inclusion of Tunisia in the EU's Horizon 2020 Research and Innovation Programme, etc.

All in all, the EU has further retreated from its democracy support role over the course of 2016 which is not a surprise given developments within the EU itself and the global crisis of democracy with the rise of populism and extreme right movements in Europe and beyond. It is, however, questionable whether stability in the neighbourhood can prevail in the long run without genuine political reform.

\section{Addressing Instability and Conflict}

Despite the EU's long-standing discourse about its key role in resolving the conflicts in its neighbourhood, it has not earned a reputation for being an effective security provider (Pomorska and Noutcheva, 2013, p. 231). While stability was identified as a key priority in the revised neighbourhood policy, the EU Global Strategy took a different approach with primary emphasis on resilience (Juncos, 2016). In this context, the European Neighbourhood Policy and the EU enlargement policy were identified as different 'paths to resilience'. Another guiding principle of the EU's external action was defined in the European Global Strategy as 'principled pragmatism' (European Union, 2016). This pragmatic discourse has marked a notable shift from the European Security Strategy in 2003, which emphasized the EU's role as a 'force for good' and its intention to promote a ring of 'well-governed countries to the East of the European Union and on the border of the Mediterranean' (Council of the EU, 2003). In this section, we show the biggest security challenges in the EU's direct neighbourhood and the way in which the Union responded.

To the East of the European Union, the conflict between Ukraine and Russia continued throughout 2016, even though it received considerably less attention in international media coverage. The inability of the EU (but also of NATO) to not only prevent, but even to foresee the war in its neighbourhood, clearly showed the weaknesses of its security policies. At the same time, Russia has become a more assertive player not only in its "near neighbourhood' but also in global politics, engaging in conflict in Syria and increasing the activities of its propaganda machinery aimed to influence the national elections not only in the United States, but also within the EU. The cyber-attacks, propaganda, the spread of 'fake news' were aimed at swaying the politics in the West. For example, the Czech domestic intelligence agency (BIS) identified the Russian intelligence services as the most active foreign intelligence services in the country. ${ }^{10}$ In response, the European External Action Service (EEAS) created a Strategic Communication Task Force in 2015 to counter Russian propaganda. In 2016, a number of Members of the European Parliament called

${ }^{10}$ EUObserver, 2 September 2016. 
for a transformation of the taskforce into a fully-fledged unit and with an increase in the budget as well as the number of staff. ${ }^{11}$ In line with the advocated pragmatic approach, the new European Global Strategy envisages a 'selective engagement' with Russia in issues such as climate, maritime security, research and cross-border co-operation. The strategy does, however, emphasize also that the EU will not accept the illegal annexation of Crimea nor the actions aimed at destabilizing eastern Ukraine.

The EU's efforts to foster peace in Ukraine that followed the so-called 'Minsk 2' peace agreement, led by the German Chancellor Angela Merkel and the French President François Hollande, had not succeeded. This was of course largely due to the fact that the agreement was destined to fail from the beginning, setting an almost impossible benchmark to the Ukrainian president Petro Poroshenko. Both sides of the conflict had different ideas of how to interpret it. For the Russians, the prerequisite for any agreement was the introduction of de-centralization reforms by Ukraine, while the Ukrainian side expected an unconditional and permanent ceasefire, accompanied by restoration of control of the Ukrainian-Russian border (Wilk et al., 2016). This is why, according to some observers, the EU should stop applying pressure on Ukraine to implement the provisions of 'Minsk 2', as they act against Ukraine's and the EU's interests (Pelczynska-Nalecz and Buras, 2017). Instead, the Union should focus on strengthening the internal reform of Ukraine in order to increase its resilience.

While there was no major escalation, the conflict did not move towards a solution, ceasefire or a military disengagement, instead the situation reached a 'stalemate'. The leaders of Germany, France, Ukraine and Russia continued meeting in the co-called Normandy format to seek a solution to the conflict. The results hitherto have not been encouraging. Indeed, it is hard to imagine what would be the incentive for Russia to treat its commitment seriously and disengage. As noted, 'the Russians are not interested in resolving frozen conflicts because they are useful instruments in extending Russian levers of power in their neighborhood'. ${ }^{12}$

The EU's relationship with Russia became even more strained following Russian involvement in Syria. For example, the bombing of Aleppo sparked some strongly phrased language in the joint statement of the EU foreign ministers after a meeting in Luxembourg on 17 October (Council of the EU, 2016b). The German Foreign Minister Frank-Walter Steinmeier said that 'Russia's role was clear'. ${ }^{13}$ While the Czech, Swedish and German ministers favoured the introduction of further sanctions, the HRVP Federica Mogherini spoke in favour of finding 'a balance of firmness and dialogue' with Russia on Syria. ${ }^{14}$ The member states were again not united in their position, even in light of Russia's involvement in Syria. During the European Council in October, the 'Big Three' backed the introduction of the new sanctions against Russian officials but such a move was blocked by the Italian Prime Minister Matteo Renzi, with the leader of Luxembourg expressing caution about the impact and effectiveness of sanctions on Russia. ${ }^{15}$ The press had reported a long and emotional discussion among the heads of

\footnotetext{
${ }^{11}$ EUObserver, 11 October 2016.

12 Politico, 20 October 2016.

13 EUObserver, 12 December 2016.

${ }^{14}$ EUObserver, 20 October 2016.

15 Politico, 14 November 2016.
} 
states and government, in particular an appeal by Chancellor Merkel and her account of the devastation in civilian areas of Aleppo after the bombings. ${ }^{16}$

The idea of imposing further sanctions was also not taken up during the official meeting of the Foreign Affairs Council (FAC) in December 2016 but the sanctions against Russia over the illegal annexation of Crimea and over non-compliance with the Minsk agreements remained in place throughout 2016, having been extended respectively in June and July and later in December. In November, the FAC also added 17 ministers and the governor of the Central Bank of Syria to the existing list of individuals under sanctions such as a travel ban and an asset freeze, which then included 234 people. The complexity of the relationship transpired when it emerged in the press that Spain had intended to allow the Syria-bound Russian ships to refuel in its port of Cuenta. After international pressure, Russia withdrew its requests for use of the port.

The Southern neighbourhood also remained in turmoil in 2016. The international community witnessed continued fighting in Syria. While the EU committed some substantial financial means in response to the conflict, including $€ 1$ billion for implementation of the Regional Strategy 2015-2016 (European Commission, 2015b), it had little political clout. The HRVP with the representatives of Germany, UK, Italy and the UK failed to make a substantial impact in the International Syria Support Group and were overshadowed by other players (Koenig, 2016). The ceasefire negotiated in December was brokered by Russia, Turkey and Iran. The lack of a coherent and unified approach to the conflict was underlined by the Commission President Jean-Claude Juncker in his State of the Union speech, when he asked: 'where is the Union, where are its Member States, in negotiations towards a settlement?' (Juncker, 2016) and called for the formulation of a political strategy towards Syria.

Overall, faced with increasing instability and on-going military conflicts in both, Eastern and Southern neighbourhoods, the member states of the EU struggled to pull their weight behind the peace-making efforts and speak with one voice. Even though the sanctions against Russia remained in place, there was little the Union could achieve to stop the hostilities. With regards to the conflict in Syria, the EU lacked a clear political strategy and focused predominantly on finding ways to deal with the refugee flows. ${ }^{17}$

\section{Conclusions}

Did the EU's efforts to promote democracy and provide security in its neighbourhood make any difference in 2016? What is most characteristic of the EU's approach to the neighbourhood is its reactive mode where various crises have been driving the foreign policy agenda with little scope for positive initiatives intended to advance the EU's long-term goals. The necessity to come up with crisis responses in the short term has brought to the surface the EU's paramount security interests in the neighbourhood, above all the need to pacify and stabilize the territories along its external borders. Democracy promotion has been relegated to a secondary status in terms of priorities and this has resulted in a weak response to the worsening political governance standards in the countries around the EU. The EU's internal problems with democratic governance have

\footnotetext{
16 Politico, 24 October 2016.

${ }^{17}$ See also Novotná's contribution to this volume.
} 
further undermined its normative appeal in the eyes of its neighbours and its power to attract others by presenting a political model worthy of emulation.

We have also shown that even faced with an increasing instability and military conflict at its borders, the EU member states could not find common ground and agree on more powerful responses. The disagreement on Russia serves as a telling example. This lack of unity has contributed to the waning influence of the EU in its neighbourhood. It also showed that even with considerable reforms in the institutional setting of European Foreign Policy, the agreement between member states remains crucial. Consensual negotiations may be encouraged by the normative environment in the Council that legitimizes co-operation but it has not yet led to convergence of opinion on the most important issues as discussed in this contribution. Without a unified approach, the EU is losing leverage and influence over a large part of its neighbourhood. While the question asked before was whether Europeans cared more about stability or democracy, they may well be waking up to the thought of being surrounded by both instability and autocracy.

\section{References}

Balkan Barometer (2016). Public Opinion Survey, Regional Cooperation Council, Bosnia and Herzegovina. Available online at: http://www.rcc.int/seeds/files/RCC_BalkanBarometer_ PublicOpinion_2016.pdf. Last accessed: 8 May 2017.

Balkans in Europe Policy Advisory Group (BiEPAG) (2017) 'The Crisis of Democracy in the Western Balkans. Authoritarianism and EU Stabilitocracy'. Policy Paper, March. Available online at: http://www.biepag.eu/wp-content/uploads/2017/03/BIEPAG-The-Crisis-ofDemocracy-in-the-Western-Balkans.-Authoritarianism-and-EU-Stabilitocracy-web.pdf. Last accessed: 8 May 2017.

Bechev, D. (2016a) 'Turkey's Failed Coup has Firmly Tightened Erdoğan's Grip on Power', LSE blog, 18 July. Available online at: http://blogs.lse.ac.uk/europpblog/2016/07/18/turkey-couperdogan/. Last accessed: 10 May 2017.

Bechev, D. (2016b) 'Europe's Refugee Crisis and the Balkans', Expert Brief, Alsharq Forum, 8 June. Available online at: http://sharqforum.org/2016/06/08/europes-refugee-crisis-and-thebalkans/. Last accessed: 8 May 2016.

Boonstra, J. (2011) 'Moldova: an EU Success Story?' FRIDE Policy Brief 92, August.

Council of the EU (2016a) 'Declaration by the High Representative on behalf of the EU on the Latest Developments in Turkey', 639/16, 8 November.

Council of the EU (2016b) 'Outcome of the Council Meeting', 13309/16, 17 October.

Council of the EU (2003) A Secure Europe in a Better World. European Security Strategy, Brussels 12 December. Available online at: www.consilium.europa.eu/uedocs/cmsUpload/ 78367.pdf.

Dandashly, A. (2015) 'The EU Response to Regime Change in the Wake of the Arab Revolt: Differential Implementation'. Journal of European Integration, Vol. 37, No. 1, pp. 37-56.

European Commission (2016a) 'Turkey 2016 Report', COM(2016) 715 final, 9 November.

European Commission (2016b) 'Rule of Law: Commission discusses latest developments and issues complementary Recommendation to Poland', Press Release, 21 December. Available online at: http://europa.eu/rapid/press-release_IP-16-4476_en.htm. Last accessed: 2 May 2017.

European Commission (2016c) 'Joint Communication to the European Parliament and the Council: Strengthening EU Support for Tunisia', Brussels, 29 September, JOIN(2016) 47 final. 
European Commission (2015a) 'Joint Communication to the European Parliament, the Council, the European Economic and Social Committee and the Committee of the Regions: Review of the European Neighbourhood Policy', JOIN(2015) 50 final, Brussels, 18 November.

European Commission (2015b) 'Joint Communication to the European Parliament and the Council: Elements for an EU Regional Strategy for Syria and Iraq as well as the Da'esh Threat', JOIN(2015) 2 final, Brussels, 6 February.

EEAS (2016) 'Statement by High Representative/Vice-President Federica Mogherini following the Meeting of the EU-facilitated Dialogue', Brussels, 27 January. Available online at: https://eeas.europa.eu/headquarters/headquarters-homepage/2966/statement-high-

representativevice-president-federica-mogherini-following-meeting-eu-facilitated_en. Last accessed: 8 May 2017.

European Union (2016) 'A Global Strategy for the European Union's Foreign And Security Policy - Shared Vision, Common Action: A Stronger Europe', Brussels, June. Available online at: http://www.eeas.europa.eu/archives/docs/top_stories/pdf/eugs_review_web.pdf. Last accessed: 5 May 2017.

Foreign Affairs Council (2016a) 'Outcome of the Council Meeting', 6122/16, Brussels, 15 February.

Freedom House (2017) Nations in Transit 2017: The False Promise of Populism (Washington DC and New York). Available online at: https://freedomhouse.org/sites/default/files/NIT2017 booklet_FINAL_0.pdf: Freedom House) Last accessed: 2 May 2017.

Hahn, J. (2016) 'Guest Editorial: Stronger Neighbourhood, Stronger Partnerships: A Revised European Neighbourhood Policy'. European Foreign Affairs Review, Vol. 21, No. 1, pp. 1-4.

Juncker, J. (2016) 'State of the Union 2016'. European Commission, Brussels 14 September.

Juncos, A. (2016) 'Resilience as the New EU Foreign Policy Paradigm: a Pragmatist Turn?' European Security, forthcoming. Available online at: http://www.tandfonline.com/doi/full/ 10.1080/09662839.2016.1247809, Last accessed: 12 May 2017.

Juncos, A. and Whitman, R. (2015) 'Europe as a Regional Actor: Neighbourhood Lost?' JCMS, Vol. 53, No. s1, pp. 200-15.

Koenig, N. (2016) 'Libya and Syria: Inserting the European Neighbourhood Policy in the European Union's Crisis Response Cycle'. European Foreign Affairs Review, Vol. 22, No. 1, pp. 19-38.

Noutcheva, G., Pomorska, K. and Bosse, G. (eds) (2013) The EU and its Neighbours. Values Versus Security in European Foreign Policy (Manchester: Manchester University Press).

Pelczynska-Nalecz, K. and Buras, P. (2017) The Minsk (Dis)agreement and Europe's Security Order (Warsaw: Heinrich Boell Stiftung and Batory Foundation).

Pomorska, K. and Noutcheva, G. (2013) 'Conclusion: Conceptualizing the EU's Role in the Neighbourhood'. In Noutcheva, G., Pomorska, K. and Bosse, G. (eds) The EU and its Neighbours. Values Versus Security in European Foreign Policy (Manchester: Manchester University Press).

Ülgen, S. (2016) 'The Anatomy of Turkey's Botched Coup'. Carnegie Europe, 19 July.

Wilson, A. (2017) 'Europe Keep an Eye on Minsk', Politico, 17 March. Available online at: http:// www.politico.eu/article/europe-keep-an-eye-on-minsk-belarus-alexander-lukashenkovladimir-putin-russia/ Last accessed: 10 April 2017.

Wilk, A., Olszanski, T. and Gorecki, W. (2016) 'The Minsk Agreement. One Year of Shadow Boxing', OSW Analyses. Available online at: https://www.osw.waw.pl/en/publikacje/ analyses/2016-02-10/minsk-agreement-one-year-shadow-boxing. Last accessed: 10 May 2017. 